\author{
Jerzy Janczewski \\ Zespół Szkół im. St. Staszica, Gąbin
}

\title{
Kryteria i miary przedsiębiorczości w małej firmie
}

Problem pomiaru przedsiębiorczości jest niezwykle złożony i trudny do wykonania gdyż brakuje jednoznacznej definicji przedsiębiorczości i wynikających z niej jednoznacznych kryteriów i miar. W to, że istnieje przedsiębiorczość nikt nie wątpi, termin dla wielu ludzi jest zrozumiały, ale różnie pojmowany. Zwykle przez pryzmat zainteresowań i uprawianej profesji. Od dwustu lat powstają różne definicje przedsiębiorczości, czasami sobie przeciwstawne, co niekiedy wprowadza zamęt intelektualny, zwłaszcza gdy chodzi o funkcjonowanie i rozwój organizacji. Można też postawić pytanie, czy przez przedsiębiorczość należy rozumieć ,wszystko" ${ }^{\text {? }}$.

Skoro próby konceptualizacji nie przynoszą oczekiwanych rezultatów i nadal przedsiębiorczość jest terminem szeroko interpretowanym to jej miary należy konstruować indywidualnie dla każdej dziedziny aktywności ludzkiej uwzględniając jej specyfikę.

Artykuł jest próbą wykorzystania różnych kryteriów mogących służyć w konstruowaniu miar przedsiębiorczości. Przeprowadzona analiza miar przedsiębiorczości może w przyszłości pomóc w wyborze tych najwłaściwszych. Szczególnie interesują mnie takie miary, które umożliwią określenie potencjału przedsiębiorczości w firmie usługowej z sektora napraw i obsługi samochodów.

Etymologiczne wyjaśnienie pochodzenia wyrazu przedsiębiorczość sugeruje, że jego źródłem są wyrazy przedsiębiorstwo i przedsiębiorca. Takie rozumowanie potwierdza fakt, że w gospodarce przedsiębiorczość najczęściej utożsamiana jest z małą firmą i działaniami jej właściciela lub menedżera i pracowników. Małą firmę tworzą ludzie i jest ona żywym organizmem, którego cechy bezpośrednio wpływają na przedsiębiorczość. Poznać i zrozumieć działania tych ludzi, to tak jakby dotrzeć do źródeł przedsiębiorczości. Jednak i takie uproszczenie nie umożliwia jej konceptualizacji i przyjęcia jednoznacznej definicji.

Obecnie na użytek badających przyjmowane są cztery ujęcia definicji (Kraśnicka 2002, Piasecki 2001, Targalski 2002, Targalski 2003) przedsiębiorczości:

- znaczeniu podstawowym, tzw. fundamentalne lub klasyczne, odwołujące się do ekonomicznych funkcji działań przedsiębiorcy w gospodarce,

- opierające się na gruncie psychologii, które koncentrują się na cechach osobowych i charakterystyce personalnej przedsiębiorcy,

- traktujące przedsiębiorczość jako rodzaj menedżerskiego zachowania (podejścia) i postrzegające ją jako specyficzny sposób zarządzania,

- uwzględniające rozumiane w szerokim znaczeniu tzw. czynniki „,społeczno-kulturowe”.

Z wielorakich ujęć definicji przedsiębiorczości wynikają różne determinanty uzyskiwania korzyści przez małe przedsiębiorstwo (tabela 1), co w konsekwencji prowadzi do identyfikacji kryteriów oceny przedsiębiorczości i ich miar.

\footnotetext{
${ }^{1}$ Mam tutaj na myśli wszystkie działania poprzedzane przymiotnikiem przedsiębiorcze, także i te, które fałszują istotę przedsiębiorczości.
} 
Tab. 1. Determinanty uzyskiwania korzyści przez małe przedsiębiorstwa wynikające z różnych ujęć przedsiębiorczości.

\begin{tabular}{|l|l|}
\hline \multicolumn{1}{|c|}{ Koncepcje przedsiębiorczości } & \multicolumn{1}{|c|}{\begin{tabular}{c}
\multicolumn{1}{c|}{ Czynniki determinujące korzystne wyniki } \\
dla małego przedsiębiorstwa
\end{tabular}} \\
\hline $\begin{array}{l}\text { 1. Koncepcje klasyczne } \\
\text { fundamentalne) }\end{array}$ & $\begin{array}{l}\text { Ocena szans uruchomienia i rozwoju przedsięwzięcia, ocena } \\
\text { szans na zebranie wymiernych efektów z przedsiębiorczych } \\
\text { działań, oszacowanie stopnia towarzyszącego tym działaniom } \\
\text { ryzyka i niepewności, kapitał do realizacji celu, stałe inwestowa- } \\
\text { nie, innowacje. }\end{array}$ \\
\hline $\begin{array}{l}\text { 2. Koncepcje opierające się } \\
\text { na gruncie psychologii }\end{array}$ & $\begin{array}{l}\text { Kreatywność, inicjatywa, innowacyjność, elastyczność, wyobraź- } \\
\text { nia, niezależność, potrzeba osiągnięć i motywacja, przywództwo, } \\
\text { gotowość do podejmowania umiarkowanego ryzyka, silna zdol- } \\
\text { ność do przekonywania, samoocena i samokontrola, umiejętność } \\
\text { komunikowania się, zdolność rozwiązywania problemów, prowa- } \\
\text { dzenia negocjacji i podejmowania decyzji. }\end{array}$ \\
\hline $\begin{array}{l}\text { 3. Koncepcje opierające się } \\
\text { na gruncie nauk o zarządzaniu }\end{array}$ & $\begin{array}{l}\text { Strategiczna orientacja, wiedza, gromadzenie i wykorzystywanie } \\
\text { informacji, podejmowanie decyzji, angażowanie się w okazję i } \\
\text { wykorzystywanie pojawiających się szans, efektywne wykorzy- } \\
\text { stanie środków, pełna kontrola nad posiadanymi zasobami, bez- } \\
\text { pośredni kontakt z pracownikami i obiektami otoczenia, ekwiwa- } \\
\text { lentny system wynagradzania za pracę, pobudzanie kreatywności, } \\
\text { kształtowanie kultury przedsiębiorczości, uwzględnianie aspek- } \\
\text { tów proekologicznych, tworzenie elastycznej struktury organiza- } \\
\text { cyjnej, usprawnienia techniczne i proceduralne, dbanie o jakość. }\end{array}$ \\
\hline $\begin{array}{l}\text { 4. Koncepcje wynikające z ,uwa- } \\
\text { runkowań } \\
\text { wych” }\end{array}$ & $\begin{array}{l}\text { Wytworzone i przekazywane systemy wartości, tradycje rodzinne } \\
\text { i regionalne, przekonania, wzorce zachowań, sposób myślenia } \\
\text { i poznania świata, uczciwość, pracowitość, rzetelność, poczucie } \\
\text { obowiązku zawodowego, dotrzymywanie umów. }\end{array}$ \\
\hline
\end{tabular}

Źródło: opracowanie własne na podstawie przeglądu definicji przedsiębiorczości w: Bielecki, 1999; Bratnicki, 2001; Drucker, 2002; Kwiatkowski, 2002; Kraśnicka, 2002; Łuczak, 2003; Piasecki, 2001; Strużycki, 2002; Targalski, 2002; Targalski, 2003.

Z przyjętych kryteriów oceny przedsiębiorczości wynikają dogodne do interpretacji miary zarówno ilościowe i jakościowe, które przedstawiłem w tabeli 2.

Kryterium rynku jako oceny przedsiębiorczości w małej firmie określa jej udział w rynku (najczęściej lokalnym). Istotne z punktu przedsiębiorczości jest to czy udział ten jest rosnący, stały lub malejący, ważna jest także ekspansja na inne rynki i lata działalności. Mała firma zaliczona jest do przedsiębiorczej, gdy jest elastyczna, tzn. zdolna do wyszukania na rynku i szybkiego zajęcia nowej niszy, zwłaszcza gdy w obrębie jej dotychczasowej działalności pojawi się silna konkurencja.

Kryterium produktu dla małej firmy jest to czy oferowany produkt jest dostępny i różni się od oferty konkurencji w tym także i ceną (np. promocyjną). W oczach klientów małych firm usługowych, zwłaszcza motoryzacyjnych (będących w obszarze zainteresowań autora), rośnie znaczenie produktu kompleksowego w rozumieniu nie tylko obsługi lub naprawy samochodu ale również zaopatrzenia w części i akcesoria.

Ważna jest także znajomość realizacji przyjętego planu sprzedaży i jej dynamiki, choć dla wielu małych firm ilościowe określenie tego kryterium jest obarczone znacznym błędem. Małe firmy niechętnie udzielają informacji o swojej sprzedaży a wiele $\mathrm{z}$ nich plany sprzedaży opiera wyłącznie na intuicyjnym szacunku ${ }^{2}$. Podobne trudności powstają w przy-

\footnotetext{
${ }^{2}$ W Polsce jedna trzecia małych przedsiębiorców planuje zaledwie na pół roku naprzód a pozostałe dwie trzecie jeszcze krócej lub wcale. Z wypowiedzi Michała Olszewskiego z Polskiej Konfederacji
} 
padku potrzeby ilościowego wyznaczenia w małej firmie kosztów marketingu lub ich udziału w kosztach własnych.

Tab. 2. Kryteria oceny przedsiębiorczości w małej firmie i ich miary.

\begin{tabular}{|c|c|c|}
\hline $\begin{array}{c}\text { Ujęcie } \\
\text { przedsiębiorczości }\end{array}$ & $\begin{array}{c}\text { Kryteria oceny } \\
\text { przedsiębiorczości }\end{array}$ & Miary kryteriów przedsiębiorczości \\
\hline \multirow{6}{*}{ Podstawowe } & Rynek & $\begin{array}{l}\text { udział w rynku, ekspansja na inne rynki, elastyczność } \\
\text { w zajmowaniu nowych nisz, czas działalności }\end{array}$ \\
\hline & Produkt & $\begin{array}{l}\text { produkt znacznie różniący się od konkurencji, dostępna } \\
\text { oferta, konkurencyjna cena, promocje sprzedaży, udział } \\
\text { kosztów marketingu w kosztach własnych, realizacja } \\
\text { planu sprzedaży, dynamika sprzedaży }\end{array}$ \\
\hline & Kapitał & $\begin{array}{l}\text { wyposażenie w maszyny i narzędzia, pozyskanie środ- } \\
\text { ków, wykorzystanie funduszy np. unijnych, kwalifikacje } \\
\text { przedsiębiorcy (menedżera), pracowników }\end{array}$ \\
\hline & Innowacje & $\begin{array}{l}\text { nowe produkty, wprowadzanie nowych technologii, } \\
\text { procedury, patenty, wzory użytkowe, usprawnienia }\end{array}$ \\
\hline & Inwestycje & skala środków na inwestycje \\
\hline & Zatrudnienie & dynamika zatrudnienia \\
\hline Psychologiczne & $\begin{array}{l}\text { Typy } \\
\text { przedsiębiorców }\end{array}$ & $\begin{array}{l}\text { administrator, racjonalizator, menedżer nastawiony na } \\
\text { wzrost firmy, innowator }\end{array}$ \\
\hline \multirow{6}{*}{$\begin{array}{l}\text { W oparciu o nauki } \\
\text { o zarządzaniu }\end{array}$} & Jakość & system jakości, certyfikaty, autoryzacje, specjalizacja \\
\hline & Wizerunek firmy & $\begin{array}{l}\text { wygląd zewnętrzny i wewnętrzny firmy, rekomendacje } \\
\text { od ważnych klientów i reputacja w otoczeniu }\end{array}$ \\
\hline & $\begin{array}{l}\text { Współpraca } \\
\text { z innymi firmami }\end{array}$ & $\begin{array}{l}\text { przynależność do izby, cechu, sieci, zrzeszanie się (przy- } \\
\text { należność do organizacji przedsiębiorców, układów } \\
\text { integracji terytorialnych, tworzenie wspólnych przedsię- } \\
\text { biorstw) }\end{array}$ \\
\hline & $\begin{array}{l}\text { Zdobywanie } \\
\text { wiedzy }\end{array}$ & $\begin{array}{l}\text { częstotliwość dokształcania się, formy dokształcania, } \\
\text { nakłady na szkolenie i doskonalenie zawodowe }\end{array}$ \\
\hline & $\begin{array}{l}\text { Wykorzystanie } \\
\text { możliwości } \\
\text { komputera }\end{array}$ & $\begin{array}{l}\text { typowe programy finansowo-księgowe, administrowanie } \\
\text { i ewidencjonowanie, własna strona internetowa, współ- } \\
\text { praca z dostawcami i klientami, zdobywanie informacji }\end{array}$ \\
\hline & $\begin{array}{l}\text { Ochrona środowiska } \\
\text { naturalnego }\end{array}$ & $\begin{array}{l}\text { działania proekologiczne, m.in. zagospodarowanie odpa- } \\
\text { dów }\end{array}$ \\
\hline \multirow{2}{*}{$\begin{array}{l}\text { „Kulturowe i spo- } \\
\text { łeczne” }\end{array}$} & Tradycje rodzinne & $\begin{array}{l}\text { przejęcie (kontynuacja) działalności, podobnie jak rodzi- } \\
\text { na }\end{array}$ \\
\hline & $\begin{array}{l}\text { Praca na rzecz } \\
\text { Środowiska }\end{array}$ & $\begin{array}{l}\text { tworzenie nowych miejsc pracy, współpraca i wspieranie } \\
\text { lokalnych organizacji. }\end{array}$ \\
\hline
\end{tabular}

Źródło: opracowanie własne z inspiracji: Bojewska B., Przedsiębiorczość w zarządzaniu i rozwoju małych i średnich przedsiębiorstw, w: Strużycki M., red. naukowy, Zarządzanie małym i średnim przedsiębiorstwem. Uwarunkowania europejskie, Difin, Warszawa 2002, s. 129; Kraśnicka $\mathrm{T}, 2002$.

Dla oceny przedsiębiorczości małej firmy istotnym kryterium jest jej kapitał, zarówno materialny, jak i niematerialny. Firma przedsiębiorcza dba o właściwe wyposażenie zapewniające odpowiednią realizację zamówień, zaś środki do realizacji tych działań może pozyskiwać wykorzystując różnorakie fundusze. Podstawę tzw. kapitału niematerialnego stanowią zatrudnieni pracownicy, którzy powinni legitymować się profesjonalnymi kwalifikacja-

Pracodawców Prywatnych w: Gołębiewska M., Zmęczeni przedsiębiorczościa, „Nowy Przemysł” nr 5(61) 2003, s. 11- 17. 
mi choć ich kwalifikacje nie muszą to być równoważne kwalifikacjom pracowników zatrudnionym w dziedzinach zaawansowanej technologii.

Ważnym kryterium oceny przedsiębiorczości są innowacje, realizuje się je poprzez wprowadzanie produktów opartych o nowe technologie lub unikatowe procedury, patenty, wzory użytkowe itp. W małych firmach, zwłaszcza usługowych, przeważają tzw. innowacje „miękkie” świadczące o specyficznych procedurach ${ }^{3}$ i cechach obsługi, które są szczególnie cenione przez klientów. Tutaj przedsiębiorczość polegać powinna na rozeznawaniu tych specyficznych cech, systematycznych działaniach utrzymujących i pogłębiających takie cechy oraz wprowadzaniu właściwych procedur.

Bezdyskusyjnym kryterium zaliczającym małą firmę do przedsiębiorczych są inwestycje, które na świecie $\mathrm{w}$ większości finansowane są z kredytu bankowego. W Polsce wiele małych firm inwestycje finansuje ze środków własnych, rodziny lub znajomych, rzadziej z innych źródeł. Zatem skala środków przeznaczanych przez małą firmę na inwestycje jest niewielka. Dla oceny przedsiębiorczości ważne jest to czy mała firma w ogóle przeznacza część swoich zysków na inwestycje zapewniające jej przyszły rozwój. Przeciwieństwem są takie małe firmy, które swoje zyski w całości przeznaczają na konsumpcję lub ich nie posiadają,

Na przedsiębiorczość małej firmy wskazuje także ruch zatrudnienia, rosnące, stałe lub malejące zatrudnienie może odpowiednio informować o rozwoju firmy. Choć nie w każdym przypadku taki miernik się sprawdza.

Miary kryteriów wynikające z psychologicznego ujęcia przedsiębiorczości wyszczególniają charakterystyczne profile psychologiczno-osobowe małych przedsiębiorców i ich cechy psychospołeczne. W literaturze opisano wiele takich typów. W niniejszym rozważaniu posłużono się badaniami T. Kraśnickiej (2002, s. 181-182) która nawiązującdo podziału zaproponowanego przez H. Leibensteina wyróżniła następujące typy przedsiębiorców indywidualnych:

- „administrator” - dąży do utrzymania istniejącego status quo (wielkości firmy, profilu produkcji itp.), nie widzi potrzeby zasadniczych zmian, niezbędne zmiany wprowadza metodą „małych kroczków”, korzysta z własnych zasobów, zwłaszcza finansowych, przedsiębiorca administrator wyłącznie polega na sobie,

- „racjonalizator” - dąży do stałego ulepszania tego co stworzył, unowocześnia produkt/usługę, organizację pracy, technologię, ostrożnie stopniowo dąży do rozwoju firmy,

- „menedżer nastawiony na wzrost firmy” - jest ukierunkowany na penetrację otoczenia pod kątem głównie zwiększenia sprzedaży, poszukiwania okazji sprzedaży, służy temu celowi rozpoznanie rynku, obserwacja konkurencji, nie jest nastawiony na istotne zmiany (wprowadza zmiany o charakterze „kosmetycznym”), zmiany mogą dotyczyć wzrostu wielkości produkcji np. poprzez zatrudnienie nowego pracownika,

- „innowator” - jest nastawiony na penetrację pod kątem wykorzystania okazji do zrobienia dobrego interesu rozumianego szerzej aniżeli wzrost sprzedaży tego samego produktu dąży do wprowadzenia zmian o charakterze innowacji i jest przekonany o ich potrzebie, choć wiążą się one z ryzykiem.

Ważnym kryterium oceny przedsiębiorczości małej firmy jest jakość jej produktu i waga jaką mała firma przykłada do tego zagadnienia. Miarą tutaj jest fakt posiadania lub wdrażania przez małą firmę systemu jakości opartego o odpowiednie normy, certyfikaty ${ }^{4}$ lub

\footnotetext{
${ }^{3}$ Przykładem może służyć procedura wymiany i naprawy szyb w firmie Andrzeja Łąpiesia pozwalająca odzyskać do ponownego użycia uszczelkę i ramkę, więcej w: Abramowicz M., Solidnie i oszczędnie, Rynek Motoryzacyjny nr 3 (52) 2002, s. 41.

${ }^{4}$ Niezależne serwisy samochodowe, których nie stać na wdrożenie norm ISO mają możliwość ubiegania się między innymi o certyfikat Przemysłowego Instytutu Motoryzacji. W: Certyfikacja uslug motoryzacyjnych, Nowoczesny Warsztat nr 12 (31) grudzień 2000, s. 5; Zwykle potwierdzeniem przynależ-
} 
autoryzacje uznanych marek. Także przesłanką jakości może być specjalizacja w określonym produkcie. W przypadku usług na jakość składa się też szybkość i solidność wykonania gdyż przeciwna sytuacja grozi utratą klienta lub gorszymi reperkusjami.

Wizerunek firmy a zwłaszcza jej wygląd zewnętrzny i wewnętrzny wyróżniający ją od pozostałych, rekomendacje od ważnych klientów i reputacja w otoczeniu to także miary przedsiębiorczości firmy

Żadna mała firma nie powinna funkcjonować w osamotnieniu, stąd ważnym kryterium oceny przedsiębiorczości jest współpraca z innymi firmami, także i z konkurencyjnymi. Miarą przedsiębiorczości jest tutaj przynależność do izby, cechu, określonej sieci ${ }^{5}$, korzystanie $\mathrm{z}$ wiedzy innych firm np. w zakresie doradztwa technicznego, prawnego lub ekonomicznego, przynależność do stowarzyszeń, tworzenie wspólnych przedsiębiorstw i układów integracji terytorialnej. Każda branża stwarza duże możliwości do współpracy ze sobą małych firm w różnych strukturach stosownie do ich bieżących potrzeb i posiadanej specjalizacji.

Umiejętności wyróżniające firmę są przede wszystkim rezultatem wykształcenia i wiedzy przedsiębiorcy (menedżera) i pracowników. Stąd kolejnym miernikiem przedsiębiorczości jest częstotliwość i formy dokształcania się przedsiębiorcy (menedżera) i pracowników małej firmy. Może on być wyrażony w postaci nakładów na szkolenie i doskonalenie zawodowe. Smutnym faktem jest to, że mali przedsiębiorcy zmuszeni do zajmowania się wszystkimi sprawami firmy nie dysponują wolnym czasem na dokształcanie i niekiedy lekceważą wiedzę jako najważniejszy kapitał firmy. Problem zdobywania podstawowych informacji, w tym i dokształcania się małych przedsiębiorców, w warunkach ustawicznego braku czasu częściowo rozwiązuje Internet. Częściowo, gdyż moim zdaniem nawet najbardziej profesjonalny przekaz multimedialny nie zastąpi bezpośredniego kontaktu wykładowcy i słuchacza.

Wykorzystanie możliwości komputera to także kryterium oceny przedsiębiorczości. Mała firma powinna wykorzystywać nie tylko typowe programy np. finansowo-księgowe, ale też za pomocą Internetu współpracować z innymi firmami, posiadać własną stronę, gromadzić informacje, prowadzi elektroniczną ewidencję usług itp.

Ważnym kryterium oceny przedsiębiorczości jest dbałość przez małą firmę o środowisko naturalne, a zwłaszcza o sposób zagospodarowania przez nią szkodliwych odpadów powstających $\mathrm{w}$ wyniku procesu produkcji lub usługi. W dziedzinie zagospodarowania odpadów firmy przedsiębiorcze powinny podejmować lokalnie inicjatywy i współpracować $\mathrm{z}$ innymi specjalizującymi się $\mathrm{w}$ utylizacji zakładami ${ }^{6}$ lub w miarę swych możliwości samodzielnie wykorzystywać tworzone na te cele przez niektóre instytucje finansowe pakiety usług $^{7}$.

Z szeroko pojmowanego „kulturowego i społecznego” ujęcia przedsiębiorczości wynikają takie miary, jak pielęgnowanie tradycji rodzinnych w postaci przejęcia lub kontynuowania podobnej działalności (w ślad za znanym sformułowaniem z „ojca na syna”), praca na rzecz lokalnego środowiska, tworzenie nowych miejsc pracy i wspomaganie innych, np. szkół. Przeciwieństwem tutaj są niektóre małe firmy, które oprócz braku „biznesowej tradycji” unikają także tworzenia nowych miejsc pracy ${ }^{8}$.

ności warsztatu samochodowego do sieci uznanej marki jest certyfikat tej marki. W: Peresada E., Formy wspótpracy firmy Bosch z warsztatami, „Autospec” nr 2(10) 2003, s. 6.

${ }^{5}$ Sieci mogą mięć różną strukturę i różne cele. Może to być sieć typu grono, terytorialnie zintegrowana sieć firm tej samej branży, sieć kooperantów wielkiej firmy, sieć typu wirtualnego, sieć oparta na porozumieniu w sprawie wspólnych zakupów sieć typu stowarzyszenie (Pierścionek, 2003, s. 322-323); Grycuk A., Koncepcja gron w teorii i praktyce zarzadzania, „Organizacja i Kierowanie” nr 3(113) 2003, s. 3-16.

${ }^{6}$ W utylizacji jest sporo racji, ,Motosklep” nr 10,15 10 -14 11 2002, s. 18-19.

${ }^{7}$ Pieniaddze na autozłomy, „Twój Biznes” nr 22 (329),27 05 2003, s. 5.

${ }^{8}$ Gołębiewska M., Zmęczeni przedsiębiorczościa, „,Nowy Przemysł” nr 5(61) 2003, s. 13. 
Wprawdzie „kulturowo-społeczne” ujęcie przedsiębiorczości w małej firmie zamyka w niniejszym artykule dyskusję nad jej miernikami ale nie oznacza to, że jest ona całkowicie wyczerpana. Dopóki nie powstanie jednoznaczna definicja przedsiębiorczości, na co na obecnym etapie nauki się nie zanosi, dopóty problem jej różnych miar i wyboru tej najwłaściwszej będzie zawsze aktualny.

\section{LITERATURA}

Bielecki W. T., Przedsiębiorczość w wirtualnym środowisku. Aspekt dydaktyczny, Wydawnictwa Naukowe Wydziału Zarządzania Uniwersytetu Warszawskiego, Warszawa 1999.

Bratnicki M., Strużyna J., red., Przedsiębiorczość i kapitat intelektualny, Wydawnictwo Akademii Ekonomicznej w Katowicach, Katowice 2001.

Drucker P. F., Myśli przewodnie Druckera, MT Biznes, Warszawa 2002.

Kwiatkowski S., Przedsiębiorczość intelektualna, Wydawnictwo Naukowe PWN, Warszawa 2002.

Kraśnicka T., Koncepcja rozwoju przedsiębiorczości ekonomicznej i pozaekonomicznej, Wydawnictwa Akademii Ekonomicznej w Katowicach, Katowice 2002.

Łuczak M., Przedsiębiorczość w zarządzaniu firma, Wyższa Szkoła Ekonomiczna w Warszawie, Warszawa 2003.

Piasecki B. (red.), Ekonomika i zarzadzanie mała firma, wydanie III, Wydawnictwo Naukowe PWN, Warszawa-Łódź 2001.

Pierścionek Z., Strategie konkurencyjności i rozwoju przedsiębiorstwa, Wydawnictwo Naukowe PWN, Warszawa 2003.

Strużycki M. (red.), Zarzadzanie małym i średnim przedsiębiorstwem. Uwarunkowania europejskie, Difin, Warszawa 2002.

Targalski J. (red.) Przedsiębiorczość i rozwój firmy, Wydawnictwo Akademii Ekonomicznej w Krakowie, Kraków 2002.

Targalski J., Przedsiębiorczość i zarządzanie, Wydawnictwo C. H. Beck, Warszawa 2003. 